\title{
Nilai Nutrisi Pakan Ayam Ras Petelur yang Dipelihara Peternak Rakyat di Pulau Lombok
}

\author{
(Nutrient Value of Laying Hens which Reared by Farmer in Lombok Island)
}

\author{
Asnawi*, Muhammad Ichsan, Ni Ketut Dewi Haryani \\ Fakultas Peternakan Universitas Mataram, Nusa Tenggara Barat, INDONESIA \\ Tlp/Fax :633603/640592 \\ *email: asnawipunia@gmail.com
}

Manuscript received: 04-10-2017. Accepted: 19 -12- 2017

\begin{abstract}
ABSTRAK
Penelitian evalusi nilai nutrisi pakan ayam ras petelur di Pulau Lombok telah dilakukan. Penelitian menggunakan metode survey yang berlokasi di empat Kabupaten di Pulau Lombok yaitu Kabupaten Lombok Barat, Lombok Tengah, Lombok Timur dan Lombok Utara. Pada masing-masing Kabupaten diambil 4 peternak ayam ras sebagai sampel dan dianalisa di Laboratorium Nutrisi Makanan Ternak Fakultas Peternakan Universitas Mataram. Data dianalisa dan ditabulasi kemudian dipresentasikan dalam bentuk diskriptif. Hasil penelitian menunjukkan bahwa semua peternak ayam ras petelur menggunakan jagung, dedak padi, dan konsentrat sebagai ransum dasar berturut-turut sebesar 43 $\% \pm 8.13,22 \% \pm 3.93$, dan $33 \% \pm 4,83$. Campuran pakan tersebut mengandungan protein sebesar $17.21 \%$ \pm 1.23 , energi metabolis $2753 \pm 63.78$, lemak kasar dan serat kasar sebesar $4.03 \% \pm 0,2$ dan $6.29 \%$ \pm 0.46 , Ca dan $\mathrm{P}$ sebesar $3.61 \% \pm 0.53$ dan $0.51 \% \pm 0.03$. Rata-rata produksi telur, konsumsi pakan, bobot telur, tebal kerabang dan nilai HU ayam ras di Pulau Lombok berturut-turut sebesar $56 \% \pm 8.68$, $114 \pm 31,25$ g.ekor $^{-1}$.hari ${ }^{-1} .61 .71 \pm 2.49$ g. $0.39 \pm 0.03 \mathrm{~mm}$ dan $90.16 \pm 4.33$. Komposisi nutrisi ayam ras petelur tersebut sudah memenuhi Standar Nasioanal Indonesia (SNI), akan tetapi produksi telur masih rendah.
\end{abstract}

Kata Kunci : Mineral, konsentrat, Vitamin

\begin{abstract}
The research of evaluation of nutrient value of laying hens which rearing by farmer in Lombok Island was conducted. Using surveys methode in four locations in Lombok Island i.e. West Lombok, Central Lombok, East Lombok, and North Lombok and four farmers sample of each. Data was analyzed in loboratorium animal nutrition Faculty of Animal Husbandry Mataram University. Data was analized and tabulated and than descriptive presented. The result show that, all of the farmer in Lombok Island use rice bran, maize, and commercial feed as elementary ration with $43 \% \pm 8.13,22 \% \pm 3.93$, and $33 \% \pm 4.83$ respectively, in addition, all farmers use feed supplements such as vitamins or mineral. Nutrition value of ration are $17.21 \% \pm 1.23$ protein, $2753 \pm 63.78$ metabolizeble energy, $4.03 \% \pm 0,2$ extract ether and $6.29 \% \pm 0,46$ fibers, $\mathrm{Ca}$ and $\mathrm{P}$ are $3.61 \% \pm 0.53$ and $0.51 \% \pm 0.03$. Average eggs production, feed consumption, egg weight, shell thickness, and Haught Unit (HU) are 56\% \pm 8.68 ,
\end{abstract}


$114 \pm 31,25$ g.ekor ${ }^{-1} \cdot$ hari $^{-1} .61 .71 \pm 2.49 \mathrm{~g}, 0.39 \pm 0.03 \mathrm{~mm}$, and $90.16 \pm 4.33$. It can be concluded that nutrient composition of laying hens in Lombok Island according to Indonesian Standard Feed, however, eggs production and quality still low.

Key words: Vitamine, concentrate, nutrient

\section{PENDAHULUAN}

Peningkatan populasi dan produksi ayam ras petelur di daerah NTB sejak tahun 2014 sampai 2015 meningkat sebesar 41,14\%, paling tinggi dibandingkan dengan daerah-daerah lain di Indonesia (Direktorat Jenderal Peternakan dan Kesehatan Hewan, 2015). Peningkatan tersebut akibat dari tingginya permintaan masyarakat terhadap telur ayam ras, sehingga para peternak tertarik untuk melakukan usaha dibidang peternakan ayam khususnya ayam petelur.

Pemasaran produk asal unggas masih terbuka lebar, terbukti dengan kebutuhan telur ayam ras di NTB masih didatangkan dari luar daerah seperti Bali dan Jawa. Usaha budidaya ayam petelur di NTB memiliki prosfek yang cukup bagus karena antara kebutuhan dan supply masih belum seimbang dimana kebutuhan telur sebanyak 1,3 juta butir per hari namun yang diproduksi baru mencapai 300.000 butir per hari. Kekurangan tersebut yang membuat telur produksi dari Jawa Timur dan Bali masuk sebanyak satu juta butir per hari.

Faktor utama yang sering terjadi diberbagai peternakan ayam petelur khususnya di NTB adalah ketersediaan bahan pakan yang berkualitas dengan harga yang sesuai. Tingginya pakan komersial mendorong peternak melakukan inovasi dengan cara meyusun pakan sendiri dengan menggunakan bahan pakan yang tersedia, akibatnya pakan yang diberikan pada ayam sering kekurangan nutrisi. Faktor kekurangan nutrisi pakan yang diberikan tersebut diduga sebagai penyebab rendahnya produktifitas ayam terutama berat dan ukuran telur yang dihasilkan.

Ukuran dan berat telur sangat besar dipengaruhi oleh nutrisi ransum seperti protein, asam amino tertentu seperti methionine dan lysine, energi, lemak total dan asam lemak esensial seperti asam linoleat. Terpenuhinya kebutuhan akan nutrisi tersebut, diharapkan bukan hanya akan menghasilkan telur berkualitas, melainkan juga ikut berperan dalam meningkatkan jumlah produksi telur. Tidak terpenuhinya kebutuhan dari salah satu nutrisi tersebut melalui asupan ransum, maka akan mengurangi berat telur, bahkan jika hal tersebut terjadi pada petelur berproduksi sebelum umur 40 minggu, bisa berakibat pada penurunan jumlah produksi telur.Atas dasar permasalahan dan dugaan sementara tersebut perlu dilakukan penelitian dengan mengevaluasi kandungan nutrisi pakan ayam ras petelur yang dipelihara oleh peternak di pulau Lombok. Hasil evaluasi tersebut dapat digunakan sebagai dasar untuk memecahkan persoalan kualitas dan produktifitas telur ayam ras yang masih rendah di Pulau Lombok.

\section{BAHAN DAN METODE}

Penelitian ini dilakukan dalam dua tahap yaitu : (1) Evaluasi komposisi bahan pakan yang diberikan peternak dan menghubungkan dengan produksi yang dihasilkan (2) Analisa Laboratorium bahan pakan yang diberikan peternak, kemudian mengkonversikan dengan komposisi yang diberikan peternak. Penelitian tahap I dilakukan untuk menjawab tujuan penelitian pertama yaitu mengevaluasi komposisi bahan pakan yang diberikan oleh peternak ayam ras petelur di empat Kabupaten di Pulau Lombok NTB yaitu Lombok Barat (Lobar), Lombok Tengah (Loteng), Lombok Timur (Lotim) dan Lombok Utara (KLU). Data diambil 
dengan berpedoman pada quesioner yang telah dipersiapkan terlebih dahulu. Dalam quesioner tersebut akan diperoleh variable umur, catatan produksi, jenis bahan pakan yang diberikan dan kualitas telur bagian luar dan dalam yang dihasilkan. Data yang diperoleh ditabulasi menggunakan MS-Excel, dan dipresentasikan secara deskriptif. Penelitian tahap II. Dilakukan melalui analisa laboratorium bahan pakan yang diberikan peternak, kemudian mengkonversikan dengan komposisi yang diberikan peternak. Analisa proksimat dan kandungan energi dilakukan di Laboratorium Nutrisi Makanan Ternak Fakultas Peternakan Universitas Mataram, sedangkan analisa kandungan asam amino dilakukan di LSIH Universitas Brawijaya Malang.

Sampel bahan pakan diambil dari setiap peternak responden, masing masing sampel diambil sebanyak 50 gram. Sampel yang telah terkumpul dianalisa di laboratorium untuk mengetahui kandungan protein, lemak, serat kasar, $\mathrm{Ca}, \mathrm{P}$, energi dan. Data ditabulasi dan dihitung menggunaakan program MS Excel, kemudian dipresentasikan secara deskriptif.

\section{HASIL DAN PEMBAHASAN}

Jenis dan Kandungan Nutrisi Bahan Pakan yang Digunakan Peternak Ayam Ras Petelur .

Dari hasil penelitian diperoleh bahwa bahan pakan yang digunakan untuk pakan ayam ras petelur di masing-masing peternak yang tersebar di Pulau Lombok berbeda-beda. Masingmasing peternak responden memiliki ciri khas tersendiri dalam menggunakan bahan pakan sebagai ransum ayam ras petelur. Pada umumnya semua peternak ayam ras petelur menggunakan dedak padi, jagung dan konsentrat sebagai ransum dasar, akan tetapi ada beberapa peternak yang menambahakan konsentrat broiler. Semua peternak menggunakan bahan pakan tambahan berupa mineral atau vitamin. Hasil analisa komposisi bahan pakan yang digunakan peternak ayam ras petelur di Pulau Lombok disajikan pada Tabel 1.

Tabel 1. Jenis kandungan nutrisi bahan pakan yang digunakan pada kelompok ternak ayam ras petelur di Pulau Lombok.

\begin{tabular}{lccccccccc}
\hline \multicolumn{1}{c}{ Nama Bahan } & $\begin{array}{c}\text { BK } \\
(\%)\end{array}$ & $\begin{array}{c}\text { EM } \\
(\mathrm{kkal.kg} \\
\left.{ }^{1}\right)\end{array}$ & $\begin{array}{c}\text { PK } \\
(\%)\end{array}$ & $\begin{array}{c}\text { LK } \\
(\%)\end{array}$ & $\begin{array}{c}\text { SK } \\
(\%)\end{array}$ & $\begin{array}{c}\text { Ca } \\
(\%)\end{array}$ & $\begin{array}{c}\text { P.Total } \\
(\%)\end{array}$ & $\begin{array}{c}\text { Meth } \\
(\%)\end{array}$ & $\begin{array}{c}\text { Lys } \\
(\%)\end{array}$ \\
\hline $\begin{array}{l}\text { Jagung kuning } \\
\text { Dedak padi }\end{array}$ & 89 & 3200 & 8.9 & 3.8 & 2.5 & 0.01 & 0.28 & 0.18 & 0.16 \\
$\begin{array}{l}\text { CaCO3 } \\
\text { Konsentrat }\end{array}$ & 91 & 1900 & 11 & 5 & 12 & 0.06 & 1.5 & 0.29 & 0.51 \\
\hline
\end{tabular}

Keterangan: $\mathrm{BK}=$ Bahan Kering, EM = Energi Metabolisme, PK =Protein Kasar, LK =Lemak Kasar, $\mathrm{SK}=$ Serat Kasar, $\mathrm{Ca}=$ Kalsium, $\mathrm{P}=$ Phospor, Meth $=$ Methionine, Lys $=$ Lysinet

Penggunaan bahan pakan ternak unggas tergantung dari ketersediaan bahan tersebut di suatu daerah. Khususnya di Pulau Lombok, bahan pakan berupa jagung, dedak padi masih melimpah dan tersedia sepanjang tahun, sehingga kelebihan produksi dijual keluar daerah seperti Bali dan Jawa Timur. Bahan pakan tambahan berupa konsentrat dan feed additive cukup tersedia di poultry shop. 
Tingkat Penggunaan dan kandungan nutrisi bahan pakan yang digunakan peternak ayam ras petelur

Tingkat (level) penggunaan masing-masing bahan pakan di Pulau Lombok berturutturut ; jagung 43\% $\pm 8,13$, dedak 22\% $\pm 3,93$, konsentrat (KLK) $33 \% \pm 4,83$. Komposisi tersebut jika mengacu pada komposisi bahan pakan pada Tabel 2, maka kandungan protein yang diperoleh sebesar 17,21\% $\pm 1,23$ ). Kandungan protein tersebut sudah mencukupi kebutuhan protein bagi ayam ras petelur yang sedang bertelur dan sesuai dengan SNI berkisar $15-18 \%$. Kandungan lemak kasar dan serat kasar yang terkandung dalam komposisi bahan pakan di Pulau Lombok diperoleh sebesar 4,03\% \%0,2 dan 6.29\% 0.46 . Kandungan tersebut masih berkisar yang direkomendasikan Standar Nasional Indonesia sebesar 2.5 - 7.0\% lemak kasar maksimal 7.0\% serat kasar. Kandungan Ca dan P campuran pakan yang diterapkan di Pulau Lombok diperoleh sebesar $3.61 \% \pm 0.53$ dan $0.51 \% \pm 0.03$. Kandungan $\mathrm{Ca}$ dan $\mathrm{P}$ tersebut sudah mencukupi kebutuhan bagi ayam ras petelur yang sedang bertelur dan sesuai dengan SNI berkisar 3,25 - 4,0 \% Ca dan 0,6 - 0,9\% P.

Salah satu unsur pakan yang sangat penting bagi ayam ras yang sedang bertelur adalah DL-Methionine. Komposisi bahan pakan yang diterapkan di Pulau Lombok kelebihan Methionin. Kandungan Methionin yang diperoleh sebesar 0,43\% lebih besar dari kebutuhan standar yaitu maksimum $0,38 \%$. Methionin adalah asam amino esensial yang mengandung sulfur, memegang peranan penting dalam tubuh hewan maupun manusia diantaranya adalah ikut serta dalam mensintesa asam amino yang mengandung sulfur lainnya (Troen et al. 2003),sebagai prekursor karnitine dan glutathionin, membantu melindungi sel dari stress oksidatif (Faang et al. 2002; Li et al., 2007; Jankowski et al. 2013). Grimble (2006), Baker (2009) dan Wu (2010) menyatakan bahwa asam amino metionin memegang peranan penting dalam metabolism pada manusia dan hewan untuk pertumbuhan dan keseimbangan nitrogen. Metionin termasuk dalam asam amino fungsional yang berperan dalam metabolisme tubuh untuk meningkatkan kesehatan, perumbuhan dan perkembangan organ reproduksi. Pembatasan asam amino metionin dalam pakan unggas dapat mempengaruhi pertambahan bobot badan, konversi pakan dan kualitas karkas. Jankowski et al. (2013) melaporkan bahwa pemberian methionin antara 0.3 sampai $1.2 \%$ pda fase awal dan 0.3 sampai $0.9 \%$ pada fase pertumbuhan memberikan indikasi pertambahan bobot badan dan konversi pakan optimum serta meningkatkan sistem kekebalan tubuh. Hasil penelitian Tingkat Penggunaan dan kandungan nutrisi bahan pakan yang digunakan peternak ayam petelur di Pulau Lombok disajikan pada Tabel 2. Hasil penelitian menunjukkan bahwa komposisi bahan pakan yang diterapkan oleh peternak ayam ras petelur di Pulau Lombok sudah memenuhi persyaratan nutrisi menurut Standar Nasional Indonesia.

\section{Produksi Telur Ayam Ras Petelur}

Tingkat produktivitas telur ayam ras petelur di Pulau Lombok disajikan pada Tabel 3. Produksi telur ayam ras di Pulau Lombok rata-rata 56\% $\pm 8,68$. Produksi tertinggi diperoleh di Kabupaten Lombok Timur sebesar 69\%, kemudian diikuti dengan Kabupaten Lombok Tengah sebesar 55\%, KLU 51\% dan Kabupaten Lombok Barat sebesar 50\%. Data produktivitas telur ayam ras di masing-masing Kabupaten disajikan pada Tabel 3. Rendahnya produksi pada daerah KLU disebabkan karena rata-rata peternak lebih banyak menggunakan jagung akan tetapi rendah konsentrat, dengan demikian kandungan protein pakan yang 
dihasilkan rendah yaitu sebesar $15.79 \%$. Kandungan protein tersebut merupakan batas minimal yang ditetapkan Standar Nasional Indonesia.

Tabel 2. Tingkat Penggunaan dan kandungan nutrisi bahan pakan yang digunakan peternak ayam ras petelur di P. Lombok

\begin{tabular}{|c|c|c|c|c|c|c|}
\hline \multirow{2}{*}{ Bahan Pakan } & \multicolumn{4}{|c|}{ Responden } & \multirow{2}{*}{ Rataan } & \multirow{2}{*}{$\mathrm{Sd}$} \\
\hline & Lotim & Loteng & Lobar & KLU & & \\
\hline Jagung kuning & 39 & 34 & 47 & 53 & 43 & 8.13 \\
\hline Dedak padi & 27 & 17 & 22 & 20 & 22 & 3.93 \\
\hline Konsentrat (KLK) & 34 & 38 & 31 & 27 & 33 & 4.83 \\
\hline Pakan Tambahan & 0,6 & 0,5 & 0,5 & 0,5 & 0,5 & \\
\hline \multicolumn{7}{|c|}{ Komposisi Nutrisi } \\
\hline Energi & 2716 & 2687 & 2785 & 2826 & 2753 & 63.78 \\
\hline Protein & 17.76 & 18.66 & 16.87 & 15.79 & 17.27 & 1.23 \\
\hline Lemak & 4.19 & 3.69 & 4.13 & 4.10 & 4.03 & 0.23 \\
\hline Serat Kasar & 6.93 & 5.98 & 6.33 & 5.92 & 6.29 & 0.46 \\
\hline $\mathrm{Ca}$ & 3.81 & 4.21 & 3.44 & 2.96 & 3.61 & 0.53 \\
\hline $\mathrm{P}$ & 0.53 & 0.53 & 0.51 & 0.47 & 0.51 & 0.03 \\
\hline Methionine & 0.46 & 0.46 & 0.43 & 0.40 & 0.43 & 0.03 \\
\hline Lysine & 0.34 & 0.30 & 0.31 & 0.30 & 0.31 & 0.02 \\
\hline
\end{tabular}

Tabel 3. Penampilan produksi ayam ras petelur di Pulau Lombok

\begin{tabular}{ccccccc}
\hline \multirow{2}{*}{ Bahan Pakan } & \multicolumn{5}{c}{ Kabupaten } & \multirow{2}{*}{$\mathrm{Sd}$} \\
\cline { 2 - 6 } & Lotim & Loteng & Lobar & KLU & Rataan nn \\
\hline Produksi Telur & 69 & 55 & 50 & 51 & 56 & 8.68 \\
Jumlah Ayam & 1030 & 1184 & 20375 & 2595 & 6296 & \\
Pemberian $(\mathrm{Kg})$ & 99 & 113 & 939 & 327 & 369 & 393.50 \\
Konsumsi/ekor/hr & 135 & 100 & 80 & 141 & 114 & 31.25 \\
Masa bertelur (mg) & 20 & 15 & 16 & 21 & 18 & 2.72 \\
\hline
\end{tabular}

Tingginya produksi telur di daerah Lombok Timur disamping akibat kandungan protein pakan yang tinggi juga diimbangi dengan pemberian yang tinggi pula. Berbeda halnnya denga KLU dimana walaupun pemberian pakan tinggi 141 g/ekor/hari akan tetapi kualitas pakan yang diberikan rendah terutama kandungan protein.

Rata-rata konsumsi ayam ras petelur pada masa peneluran pertama di Pulau Lombok sebesar $141 \mathrm{~g} / \mathrm{ekor} / \mathrm{hari}$. Angka ini sesuai dengan standar konsumsi ayam ras petelur berkisar 100-120 g/ekor/hari.

Secara umum produksi telur rata-rata ayam ras petelur di Pulau Lombok masih tergolong kecil, hal ini akibat dari masa pemeliharaan ayam yang sudah melewati batas produksi maksimal. Masa produksi ayam ras petelur berkisar 8 sampai 12 bulan. Sedangkan dalam penelitian dijumpai peternak memelihara ayam rata-rata 18 bulan masa bertelur. Produksi telur setiap minggu di masing-masing Kabupaten disajikan pada Gambar 1.

Berdasarkan Gambar 1. produksi maksimal dicapai pada umur peneluran 9 minggu sampai 25 minggu. Jadi peneluran maksimum diperoleh selama 14 minggu atau 3,5 bulan. 


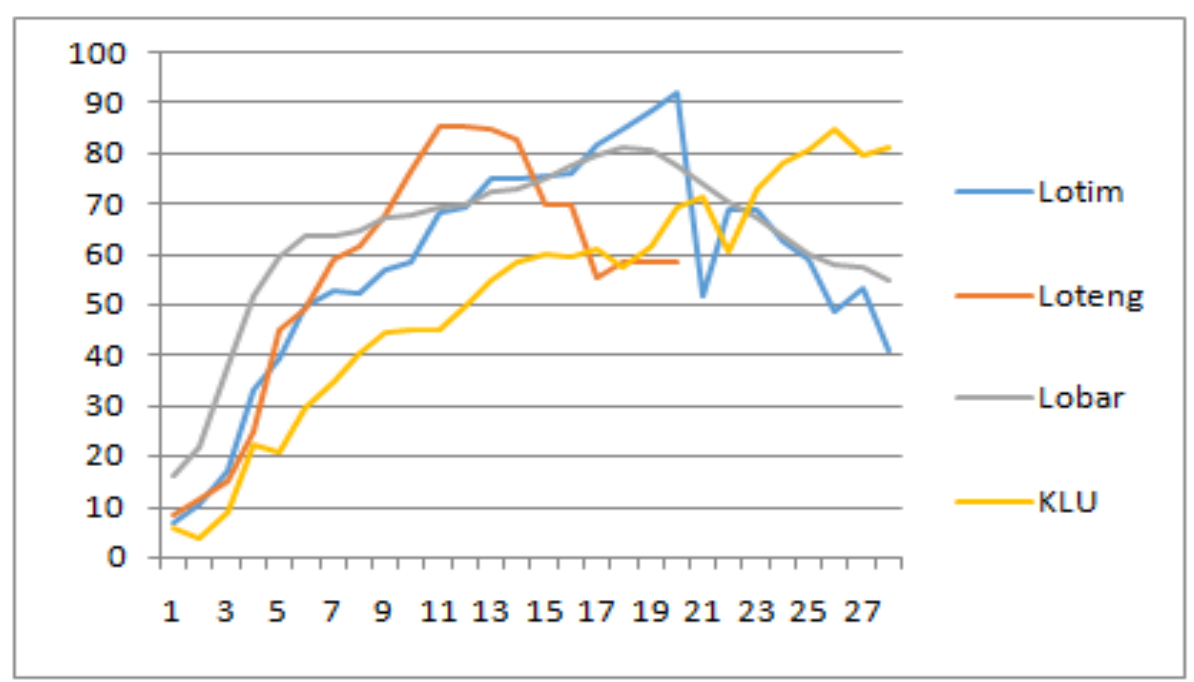

Gambar 1. Grafik produksi telur ayam ras petelur di masing-masing Kabupaten di Pulau Lombok

\section{Konsumsi Pakan}

Konsumsi pakan ayam ras petelur di Pulau Lombok rata-rata sebesar 114 $\pm 31,25$ g/ekor/hari. Konsumsi tertinggi diperoleh pada peternak di wilayah KLU sebesar 141 g/ekor/hari dikuti oleh Kabupaten Lombok Barat sebesar 80 g/ekor/hari, Lombok Tengah 100 g/ekor/hari, dan Lombok Timur sebesar 135 g/ekor/hari. Besarnya perbedaan konsumsi masing-masing kabupaten akibat dari pengetahuan peternak yang masih kurang memadai dalam pemeliharaan ayam ras petelur.

\section{Masa Bertelur}

Hasil penelitian menunjukkan bahwa rata-rata masa bertelur ayam ras petelur di Pulau Lombok sebesar 18 $\pm 2,71$ minggu. Dari grafik produksi terlihat bahwa ayam mulai menunjukan produksi maksimal pada umur peneluran 11 minggu dan terjadi penurunan produksi pada umur peneluran 25 minggu. Jadi masa maksimal produksi telur diperoleh selama 14 minggu atau 3,5 bulan. Masa produksi maksimal ini tergolong singkat jika dibandingkan dengan standar bahwa masa maksimal produksi diperoleh selama 8-12 bulan. Hal ini disebabkan karena kualitas pakan yang diberikan masih rendah terutama kandungan asam amino methionin.

\section{Kualitas Telur}

Kualitas telur dibagi menjadi dua parameter yaitu kualitas telur bagian luar dan kualitas telur bagian dalam. Kualitas telur bagian luar ditentukan oleh besarnya parameter bobot telur, indeks bentuk telur, ketebalan kerabang, dan bobot kerabang. Sedangkan kualitas telur bagian dalam ditentukan oleh nilai HU, berat albumen dan kuning telur, serta kadar kolestrol kuning telur.

Hasil penelitian menunjukkan bahwa rata-rata bobot telur ayam ras di Pulau Lombok sebesar $61.71 \pm 2.49$ g. Kabupaten Lombok Tengah memiliki bobot telur paling tinggi yaitu

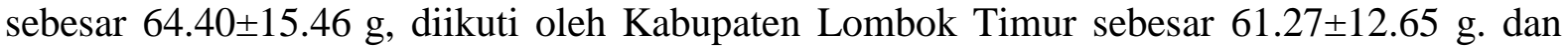
Kabupaten Lombok Barat sebesar 59.47 \pm 16.20 g. Menurut Wahju (1997) faktor yang 
mempengaruhi berat telur diantaranya adalah besarnya kandungan protein dalam pakan yang dikonsumsi. Semakin tinggi kandungan protein pakan akan mengakibatkan bobot telur yang dihasilkan juga tinggi. Masing-masing campuran pakan mempunyai kandungan protein yang berbeda, dimana Kabupaten Lombok Tengah rata-rata kandungan protein pakan yang digunakan sebesar 18,66\%. Lombok Timur sebesar 17,76\% dan Lombok Barat sebesar 16,87\%. Hasil penelitian ditunjukkan pada Tabel 4.

Tabel 4. Kualitas telur bagian luar ayam ras petelur yang dipelihara di masing-masing Kabupaten di Pulau Lombok.

\begin{tabular}{ccccc}
\hline $\begin{array}{c}\text { Kualitas Telur } \\
\text { Bagian Luar }\end{array}$ & Lotim & Loteng & Lobar & Rataan \\
\hline Bobot Telur & $61.27 \pm 12.65^{\mathrm{b}}$ & $64.40 \pm 15.46^{\mathrm{a}}$ & $59.47 \pm 16.20^{\mathrm{c}}$ & $61.71 \pm 2.49$ \\
Lebar Telur & $42.97 \pm 5.91^{\mathrm{c}}$ & $45.53 \pm 4.90^{\mathrm{a}}$ & $44.00 \pm 3.76^{\mathrm{b}}$ & $44.17 \pm 1.29$ \\
Panjang Telur & $57.03 \pm 3.46^{\mathrm{b}}$ & $57.83 \pm 3.47^{\mathrm{a}}$ & $56.63 \pm 5.45^{\mathrm{c}}$ & $57.16 \pm 0.61$ \\
Volume & $55.00 \pm 15.10^{\mathrm{a}}$ & $54.33 \pm 13.50^{\mathrm{b}}$ & $49.00 \pm 14.18^{\mathrm{c}}$ & $52.78 \pm 3.29$ \\
Tebal Kerabang & $0.36 \pm 0.06$ & $0.40 \pm 0.02$ & $0.41 \pm 0.00$ & $0.39 \pm 0.03$ \\
Berat Kerabang & $6.40 \pm 0.26^{\mathrm{c}}$ & $7.37 \pm 1.04^{\mathrm{a}}$ & $6.90 \pm 1.15^{\mathrm{b}}$ & $6.89 \pm 0.49$ \\
Index Telur & $75.11 \pm 6.22^{\mathrm{b}}$ & $78.60 \pm 4.50^{\mathrm{a}}$ & $75.11 \pm 6.22^{\mathrm{b}}$ & $76.27 \pm 2.01$ \\
\hline
\end{tabular}

Keterangan: Huruf yang berbeda pada baris yang sama menunjukkan berbeda tidak nyata $(\mathrm{p}>0.05)$

Berat kerabang telur ayam ras di Kabupaten Lombok Tengah sebesar 7.37 \pm 1.04 g.butir ${ }^{-1}$ paling tinggi dibandingkan dengan Kabupaten Lombok Barat dan Lombok Timur yaitu sebesar $6.90 \pm 1.15 \mathrm{~g} /$ butir dan $6.40 \pm 0.26 \mathrm{~g}^{\text {. butir }}{ }^{-1}$. Bobot kerabang berhubungan erat dengan bobot telur, semakin tinggi bobot telur akan mengakibatkan bobot kerabang juga tinggi. Stadellman dan Cotterill (1994) menyatakan bahwa berat kerabang telur berkisar antara 9 sampai $12 \%$ dari total berat telur. Menurut Curtis et al. (1985) semakin tinggi Ca semakin tinggi pula bobot maupun tebal kerabang telur. Menurut Yuanta et al. (1992) kualitas telur dipengaruhi oleh beberapa faktor yaitu konsumsi pakan, konsumsi $\mathrm{P}$, dan pengaturan cahaya.

Tebal kerabang telur ayam ras di Pulau Lombok sebesar $0.39 \pm 0.03 \mathrm{~mm}$. Tebal kerabang telur di semua kabupaten yang ada di Pulau Lombok berbeda tidak nyata $(\mathrm{P}>0,05)$. Hal ini desebabkan karena kandungan nutrisi pakan terutama kandungan $\mathrm{Ca}$ dan $\mathrm{P}$ pakan yang diberikan sama. Menurut Wahju (1997) kualitas kerabang telur ditentukan oleh ketebalan dan struktur kerabang. Kandungan $\mathrm{Ca}$ dan $\mathrm{P}$ dalam pakan berperan terhadap kualitas kerabang telur karena dalam pembentukan kerabang telur diperlukan adanya ion-ion karbonat dan ionion Ca yang cukup untuk membentuk $\mathrm{CaCO} 3$ kerabang telur.

Indeks bentuk telur adalah nilai persentase perbandingan lebar telur dengan panjang telur. Romanoff dan Romanoff (1963) menyatakan bahwa bentuk telur yang ideal adalah 73,68 \%. Jull (1951) menyatakan banhwa indeks bentuk telur menunjukkan tingkat kelonjongan telur. Semakin besar angka indeks berarti bentuk telur akan mengarah ke bulat sempurna. Dalam penelitian ini diperoleh hasil bahwa ayam ras di pulau Lombok memiliki indeks bentuk telur yang normal (lonjong). North dan Bell (1990) menyatakan bahwa bentuk telur ditentukan dalam saluran reproduksi induk. Bentuk spesifik telur akan berubah karena adanya kelainan atau kondisi yang tidak biasa pada daerah magnum, itsmus dan uterus. 
Sebagian besar bentuk telur ditentukan oleh jumlah albumin yang disekresikan dalam saluran telur, ukuran lumen, aktifitas dan kekuatan otot dinding isthmus serta kemungkinan terjadinya perubahan bentuk dalam uterus.

\section{Kualitas telur bagian dalam}

Kualitas telur bagian dalam ditentukan oleh besarnya parameter tinggi albumin, bobot albumen, bobot kuning telur dan indeks warna kuning telur (yolk). Hasil penelitian kualitas telur bagian dalam disajikan pada Tabel 5 .

Tabel 5. Kualitas telur bagian dalam ayam ras petelur yang dipelihara di masing-masing Kabupaten di Pulau Lombok

\begin{tabular}{ccccc}
\hline $\begin{array}{c}\text { Kualitas Telur } \\
\text { Bagian Dalam }\end{array}$ & \multirow{2}{*}{ Lotim } & Loteng & \multirow{2}{*}{ Lobar } & \multirow{2}{*}{ Rataan } \\
\hline Berat Putih $(\mathrm{g})$ & $35.43 \pm 11.67^{\mathrm{c}}$ & $36.67 \pm 11.39^{\mathrm{a}}$ & $36.10 \pm 11.85^{\mathrm{b}}$ & $36.07 \pm 0.62$ \\
Tinggi Putih Telur (mm) & $3,71 \pm 0,10^{\mathrm{a}}$ & $3,72 \pm 0,24^{\mathrm{a}}$ & $5,38 \pm 1,34^{\mathrm{b}}$ & $4,27 \pm 0,56$ \\
Berat Kuning (g) & $14.90 \pm 1.31^{\mathrm{b}}$ & $17.30 \pm 2.77^{\mathrm{a}}$ & $14.83 \pm 2.85^{\mathrm{c}}$ & $15.68 \pm 1.41$ \\
Warna Kuning Telur & $6.67 \pm 1.53^{\mathrm{c}}$ & $8.33 \pm 0.58^{\mathrm{b}}$ & $12.00 \pm 0.00^{\mathrm{a}}$ & $9.00 \pm 2.73$ \\
Diameter Rongga Udara (mm) & $18.90 \pm 6.30^{\mathrm{a}}$ & $18.20 \pm 5.24^{\mathrm{b}}$ & $17.37 \pm 5.59^{\mathrm{c}}$ & $18.16 \pm 0.77$ \\
Haugh unit & $90,73 \pm 4,21$ & $91,62 \pm 5,07$ & $88,13 \pm 3,71$ & $90,16 \pm 4,33$ \\
\hline
\end{tabular}

Keterangan: Huruf yang berbeda pada baris yang sama menunjukkan berbeda tidak nyata $(\mathrm{p}>0.05)$

Tinggi rendahnya albumin telur menunjukkan tingkat kekentalan telur. Semakin tinggi albumn menandakan bahwa telur tersebut lebih kental. Telur yang kental memberikan kualitas yang lebih baik. Hasil penelitian menunjukkan bahwa tinggi putih telur ayam ras di Kabupaten Lombok Barat lebih tinggi dibandingkan dengan Kabupaten Lombok tengah dan Lombok Timur $(\mathrm{P}<0,05)$ hal ini akibat dari penggunaan jagung yang tinggi di Kabupaten Lombok Barat sehingga akibatnya tinggi putih telur akan berpengarauh. Menurut Wahju (1997) kekentalan telur dapat dilihat dari tinggi albumin, dipengaruhi oleh pakan dan lama penyimpanan

Warna kuning telur ayam ras di Kabupaten Lombok Barat mencapai sempurna yautu skor 12.00. Hal ini disebabkan karena di Kabupaten Lombok Barat penggunaan jagung sebagai pakan ayam ras paling tinggi yaitu sebesar $47 \%$, sedangkan di Kabupaten Lombok Timur sebesar 39\% dan Lombok Tengah sebesar 34\%. Hal ini disebabkan karena jagung merupakan bahan yang mengandung xantophil yang memberikan warna yolk semakin kuning.

Rataan bobot kuning ayam ras petelur di Pulau Lombok sebesar $15.68 \pm 1.41 \mathrm{~g}$. Bobot kuning telur ayam ras di Kabupaten Lombok Timur diperoleh sebesar $14.90 \pm 1.31 \mathrm{~g}$ dan $17.30 \pm 2.77 \mathrm{~g}$, secara statistik berbeda nyata $(\mathrm{P}<0,05)$. Faktor yang mempengaruhi berat yolk adalah kandungan lemak dan protein dalam telur yang sebagian besar terdapat dalam yolk. Konsumsi protein dapat mempengaruhi tinggi yolk sedangkan indeks yolk dipengaruhi oleh tinggi yolk (Stadellman dan Cotterill, 1995).

Hasil penelitian nilai Haugh Unit telur ayam ras di Pulau Lombok diperoleh sebesar $90,16+4,33$. Nilau HU antar Kabupeten Lombok Barat, Lombok Timur dan Lombok tengah berbeda tidak nyata $(\mathrm{P}>0,05)$. Ini berarti bahwa pada saat pengambilan sampel dilakukan 
dalam waktu yang tidak lama sejak telur dikeluarkan (oviposisi). Faktor yang mempengaruhi HU adalah kekentalan albumin. Semakin kental albumin akan mengakibatkan HU semakin tinggi. Kekentalan albumin tersebut disebabkan karena adanya struktur gel di dalam albumen yang terbentuk di dalam istmush. Struktur gel tersebut disebabkan oleh adanya protein yang mengandung karbohidrat tinggi yaitu ovomucin. Ovomucin yang meningkat akan meningkatkan Haugh unit (Scoot et al., 1982). Pada penelitian ini konsumsi pakan masingmasing perlakuan berbeda tidak nyata, sehingga asupan protein yang diperoleh jumlahnya sama. Dengan demikian tidak berbedanya HU pada penelitian ini karena asupan protein yang sama pada masing-masing perlakuan. Haugh Unit (HU) adalah indikator untuk menilai kesegaran telur. Nilai HU dipengaruhi oleh lama simpan telur. Semakin cepat telur diukur semakin tinggi nilai HU telur, artinya telur tersebut semakin segar, begitu pula sebaliknya. Hasil penelitian ini memberikan berpengaruh tidak nyata antar kabupaten disebabkan pula karena waktu pengambilan dan pengukuran telur seragam yaitu pada pagi hari beberapa saat setelah telur mengalami oviposisi. North dan Bell (1990) menyatakan pada umumnya nilai Haugh Unit menggambarkan umur penyimpanan telur dan umur induk yang menghasilkannya. Nilai HU tidak dipengaruhi oleh susunan pakan selama imbangan protein dan energi metabolis dalam pakan yang diberikan sama.

\section{KESIMPULAN}

1. Jenis bahan pakan ayam ras petelur yang digunakan di Pulau Lombok terdiri dari jagung, dedak padi dan konsentrat ayam petelur (KLK). Tingkat penggunaan bahan pakan tersebut di setiap kabupaten berbeda-beda. Kabupaten Lombok Barat menggunakan Jagung paling tinggi yaitu sebesar $47 \%$ diikuti dengan Lombok Timur dan Lombok Tengah sebesar 39\% dan 34\%.

2. Produktivitas telur ayam ras yang dipelihara di Pulau Lombok masih rendah jika dibandingkan dengan standar produksi yang ditetapkan perusahaan pembibit.

3. Kualitas telur ayam ras di Pulau Lombok jika dilihat dari bobot telur dapat dikatakan masih rendah sedangkan dari indikator yang lain sudah mencukupi.

\section{Ucapan Terima Kasih}

Ucapan terimaksih disampaikan kepada Ristekdikti yang telah memberikan dana melalui skim penelitian Penelitian Produk Terapan dan PNBP Universitas Mataram.

\section{DAFTAR PUSTAKA}

Baker. D.H. 2009. Advances in protein-amino acid nutrition of poultry. Am. Aci., 37: 29-41

Curtis, PA, Gardner, FA and Mellor, DB. 1985. A comparison of selected quality and compositional characteristics of brown and white shell eggs. I. Shell quality. Poultry Science 64: 297-

Direktorat Jendral Peternakan dan Kesehatan Hewan. 2015. Rancangan Keterpaduan Program dan Kegiatan FokusKomoditas dan Lokasi Tahun 2015. Disampaikan Pada : Musrenbangtan Tahun 2014. Jakarta, 13 Mei 2014.

Fang Y.Z., Yang S., WuG. 2002. Free radicals, antioxidants, and nutrition. Nutrition, 18: 872-879. 
Grimble R.F. 2006. The effects of sulfur amino acid intake on immune function in humans. J. Nutr., 136: 1660-1665

Jankowski J., Magdalena Kubińska1, Zenon Zduńczyk 2013. The nutritional and immunomodulatory function of methionine in poultry diets - a revew. Anim. Sci., Vol. 14, No. 1 (2014) 17-31.

Jull, M.A. 1979. Poultry Husbandry. 3rd Ed. McGraw Hill Book Co. New York

Li P., Yin YL., Li D., Kim S.W., Wu G. (2007). Amino acids and immune function. Brit. J. Nutr.98: 237-252.

North, M.O. and D.D. Bell. 1990. Commercial Chicken Production Manual. $3^{\text {rd }}$ Ed. Van Mostand Reinhold. New York.

NRC. 1994. Nutrient Requirement of Poultry. 9th. Rev. Ed. National Academi of Science. Washington. D.C

Romanoff, A.L., and A.J. Romanoff. 1963. The Avian Egg. $3^{\text {rd }}$. John Willey and Sons. Inc. New York

Scott, M.L., M.C. Nesheim and R.J. Young. 1982. Nutrition of the Chicken. M.L. Scott and Associate, New York

Stadellman, W.S. and O.J. Cotterill. 1995. Quality Identification of Shell Egg in Egg Science and Techonology. W. J. Stadellman and O.J Cotterill ed. Avi. Publishing Co. Inc. Wesport, Connecticut.

Troen, A.M., Lutgens E., Smith D.E., Rosenberg I.H., Selhub J. 2003. The atherogenic effect of excess methionine intake. Proc. Natl. Acad. Sci. USA, 100: 15089-15094.

Wahju, J. 1997. Ilmu Nutrisi Unggas. Gadjah Mada University Press, jogyakarta

Yuanta, T., Zuprizal, Endang S.R.,dan R. Sutrisno. 2011. Kontribusi pencernaan fermentatif itik yang menggunakan limbah industry pertanian sebagai sumber serat kasar dalam pakan. http://www.digilib.ugm

Wu, G. 2010. Functional amino acids in growth, reproduction, and health. Adv. Nutr. 1: 3137. 